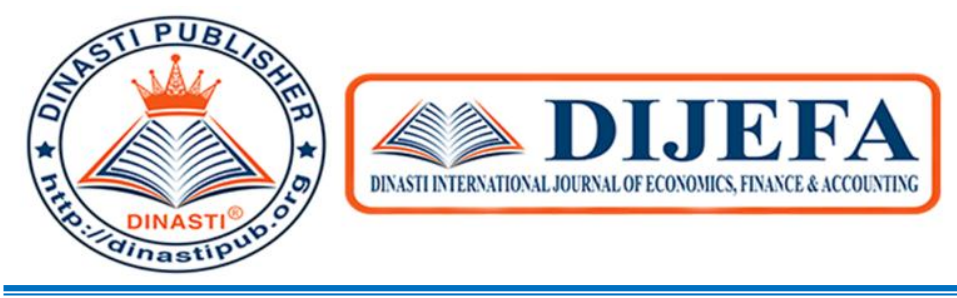

+6281387654578 ?

+6281387654578 @

https://dinastipub.org/DIJEFA (7)

dinasti-info@gmail.com @.

\title{
CAPITAL STRUCTURE DETERMINANTS OF PLANTATION SUB-SECTOR COMPANIES IN INDONESIA STOCK EXCHANGE PERIOD 2014 - 2018
}

\section{Septian Wildan Mujaddid ${ }^{1)}$, Bambang Santoso Marsoem ${ }^{2)}$}

1) Postgraduate Student, Mercu Buana University, Jakarta, Indonesia

2) Postgraduate Lecturer, Mercu Buana University, Jakarta, Indonesia

\begin{tabular}{|c|l|}
\hline $\begin{array}{c}\text { ARTICLE INFORMATION } \\
\text { Received: } 2^{\text {nd }} \text { June } 2020 \\
\text { Revised: } 25^{\text {th }} \text { June } 2020 \\
\text { Issued: } 30^{\text {th }} \text { July } 2020\end{array}$ & $\begin{array}{l}\text { Abstract: The purpose of this study is to analyze the } \\
\text { factors that influence the Debt to Asset Ratio which is } \\
\text { a proxy of Capital Structure as the dependent variable. } \\
\text { The independent variables studied as determinants of } \\
\text { Capital Structure (DAR) include Size (SIZE), } \\
\text { Profitability (ROA), Asset Structure (SA), and } \\
\text { Corporate Liquidity (CR) using regression model. } \\
\text { The population in this study are plantation sub-sector } \\
\text { companies listed on the Indonesia Stock Exchange for } \\
\text { the period 2014 - 2018. The findings suggest that ROA } \\
\text { negatively significant affect DAR, while SA positively } \\
\text { significant affect DAR. On the other hand, both SIZE } \\
\text { \& CR have no significant relationship with DAR. }\end{array}$ \\
$\begin{array}{c}\text { Eildanmujaddid @gmail.com } \\
\text { b_marsoem@yahoo.com }\end{array}$ & Keywords: DAR, ROA, SA, CR \\
\hline DOI: 10.38035/DIJEFA &
\end{tabular}

\section{INTRODUCTION}

The agricultural sector has an important role in the Indonesian economy with a contribution to Gross Domestic Product (GDP) reaching 12.81 percent or ranks third after processing and trade in 2018 (BPS, 2019). In addition to playing a role in the formation of GDP, the agricultural sector is also the business sector that absorbs the most labor in Indonesia. The following is a comparison chart of the four main employment sectors throughout 2011 - 2018 which shows the dominance of the agricultural sector. 


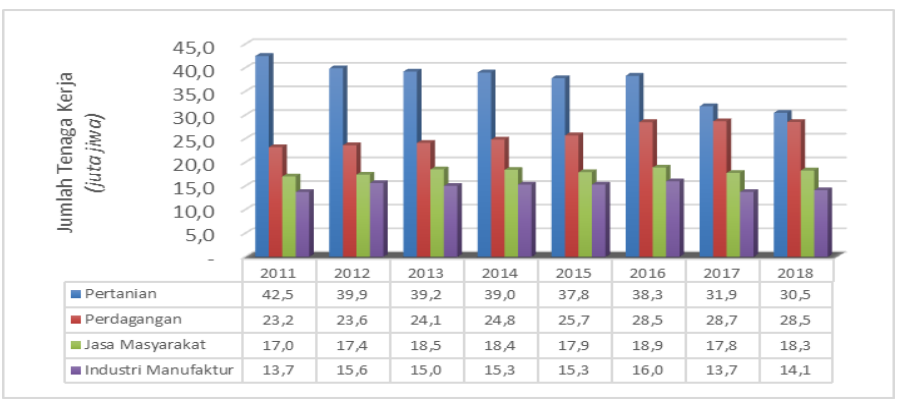

Source: BPS (2019), processed by researchers

Figure 1. Comparison of Workers who work in Major Business Fields in Indonesia period 2011 - 2018

This is also reflected in the majority of the business sectors of agricultural sector issuers, in which 18 out of 20 agricultural sector listed companies listed on the Indonesia Stock Exchange (IDX) as at 31 December 2018 were companies engaged in plantations with oil palm as its main commodity.

Table 1. Agricultural Sector Issuers on the Indonesia Stock Exchange in 2018

\begin{tabular}{clc}
\hline \hline No. & \multicolumn{1}{c}{ Subsector } & Number of Issuers \\
\hline \hline 1 & Food Crops & 1 \\
2 & Plantation & 18 \\
3 & Fishery & 1 \\
\hline & & Amount \\
\hline
\end{tabular}

Source: IDX, processed by researchers (2019)

Palm oil is the main commodity of plantation products in Indonesia which acts as a producer of foreign exchange besides oil and gas. As the world's largest producer and exporter of palm oil, in 2017 the foreign exchange contribution of palm oil commodity exports reached USD 20,724,000,000 or around Rp240 trillion, outperforming foreign exchange from other commodities (GAPKI, 2019).

\section{LITERATURE REVIEW}

\section{Agency Theory}

Agency theory is a theory put forward by Jensen \& Meckling (1976) in their research entitled "Theory of the Firm: Managerial Behavior, Agency Cost and Ownership Structure". The theory explains the potential problems that arise, which are often referred to as agency relationships, when someone or more (the principal) employs another person (the agent) to carry out some activities on their behalf (the principal) which involve the delegation of authority in decision making by the agent. The agency relationship itself is an agreement in which one or more people (owners) are involved with another person (agent) to perform several services on their behalf, which entails entrusting some of the decision making power to the agent (Jensen and Meckling, 1976). 


\section{Asymmetric Information Theory}

The financial statements are prepared to be used by various parties, including the internal company itself such as managers, employees, labor unions, and others. The parties with the most interests in the financial statements are external users (shareholders, creditors, the government, the public). One challenge that will arise between agents and principals is the information asymmetry (information asymmetry).

\section{Pecking Order Theory}

Pecking order theory is based on conditions where management has more information about the company rather than shareholders, or which investors have less information than company management about the value of the company. Those difference in information is referred to the information asymmetry. Pecking order theory assumes that companies prefer the use of internal financing sources rather than external financing. The use of external financing sources in the form of debt and issuance of shares to the public is the last choice after the source of internal source of financing runs out.

\section{Modigliani-Miller's Capital Structure Concept (MM Theory)}

Capital structure is a concept regarding the proportion of funding of company assets that comes from short-term debt, long-term debt and company equity (Utami \& Damayanti, 2018). The approach commonly used to measure a company's capital structure is to use Debt to Equity Ratio (DER) and Debt to Asset Ratio (DAR). DER shows the ratio between the company's total liabilities compared to its total equity, while DAR shows the company's total liabilities compared to their total assets. The theory was introduced by Modigliani \& Miller (1958) in his article entitled "Capital Costs, Corporate Finance, and Investment Theory" of the company. Modigliani and Miller assess the value of a company that has debt $\left(V_{L}\right)$ is the same as the value of a company that has no debt $\left(V_{U}\right)$.

\section{Modigliani Theory - Miller with Taxes}

Modigliani - Miller (MM) approach to tax is a continuation of the MM without tax approach proposed by Modigliani \& Miller (1958). In the MM approach without tax, Modigliani and Miller argue that the policy in determining the composition of the company's capital structure has no influence on firm value. Modigliani and Miller argue that the value of a company that has debt $\left(\mathrm{V}_{\mathrm{L}}\right)$ is the same as the value of a company that has no $\operatorname{debt}\left(\mathrm{V}_{\mathrm{U}}\right)$.

$$
V_{L}=V_{U}+\text { Tax Shield }
$$

\section{Trade-Off Theory}

The trade-off theory was first introduced by Modigliani \& Miller (1963) in their article entitled "Corporate Income Taxes on the Cost of Capital: A Correction". The article was issued to refine their initial model which previously took into account company tax but ignored individual tax. 


\section{Previous Studies}

Here are some of the previous studies from national journals which is a reference in this study:

Table 2. Previous Studies from National Journals

\begin{tabular}{|c|c|c|c|c|c|c|}
\hline \multirow[t]{2}{*}{ No. } & \multirow{2}{*}{$\begin{array}{c}\text { Researcher \& } \\
\text { Year }\end{array}$} & \multirow[t]{2}{*}{ Method } & \multicolumn{4}{|c|}{ Independent Variable } \\
\hline & & & Firm Size & $R O A$ & $S A$ & $C R$ \\
\hline 1. & $\begin{array}{l}\text { Nugroho, } \\
\begin{array}{l}\text { Dani, et. } \\
(2011)\end{array}\end{array}$ & $\begin{array}{l}\text { Multiple } \\
\text { linear } \\
\text { regression }\end{array}$ & $(+) \operatorname{sig}$ & & $(+) \operatorname{sig}$ & (+) sig \\
\hline 2. & $\begin{array}{l}\text { Margaretha, } \\
\text { Farah \& Aditya } \\
\text { RR (2010) }\end{array}$ & $\begin{array}{l}\text { Multiple } \\
\text { linear } \\
\text { regression }\end{array}$ & $(+) \operatorname{sig}$ & Not sig & Not sig & Not sig \\
\hline 3. & $\begin{array}{l}\text { Joni \& Lina } \\
(2010)\end{array}$ & $\begin{array}{l}\text { Multiple } \\
\text { linear } \\
\text { regression }\end{array}$ & Not sig & (-) sig & & \\
\hline 4. & $\begin{array}{l}\text { Sudarno, Riza FH } \\
\text { (2013) }\end{array}$ & $\begin{array}{l}\text { Multiple } \\
\text { linear } \\
\text { regression }\end{array}$ & $(+) \operatorname{sig}$ & (-) sig & Not sig & \\
\hline 5. & $\begin{array}{l}\text { Yusintha, P \& } \\
\text { Erni Suryandari } \\
(2010)\end{array}$ & $\begin{array}{l}\text { Multiple } \\
\text { linear } \\
\text { regression }\end{array}$ & (+) sig & (-) sig & Not sig & \\
\hline 6. & Ridloah, S (2011) & $\begin{array}{l}\text { Multiple } \\
\text { linear } \\
\text { regression }\end{array}$ & Not sig & (-) sig & Not sig & (+) sig \\
\hline 7. & $\begin{array}{l}\text { Liem, JH et. al } \\
\text { (2013) }\end{array}$ & $\begin{array}{l}\text { Multiple } \\
\text { linear } \\
\text { regression }\end{array}$ & Not sig & (-) sig & (+) sig & \\
\hline 8. & $\begin{array}{l}\text { Hartoyo, AKW, } \\
\text { et. al (2014) }\end{array}$ & $\begin{array}{l}\text { Multiple } \\
\text { linear } \\
\text { regression }\end{array}$ & Not sig & Not sig & Not sig & \\
\hline 9. & $\begin{array}{l}\text { Nuswandari, } \\
\text { Cahyani (2013) }\end{array}$ & $\begin{array}{l}\text { Multiple } \\
\text { linear } \\
\text { regression }\end{array}$ & $(+) \operatorname{sig}$ & (-) sig & & \\
\hline 10. & $\begin{array}{l}\text { Maryanti, Eny } \\
(2016)\end{array}$ & $\begin{array}{l}\text { Multiple } \\
\text { linear } \\
\text { regression }\end{array}$ & & Not sig & Not sig & \\
\hline
\end{tabular}

Source: Processed by researchers 
Table 2. Previous Studies from International Journals

\begin{tabular}{|c|c|c|c|c|c|c|}
\hline \multirow[t]{2}{*}{ No. } & \multirow{2}{*}{$\begin{array}{c}\text { Researcher \& } \\
\text { Year }\end{array}$} & \multirow[t]{2}{*}{ Method } & \multicolumn{4}{|c|}{ Independent Variable } \\
\hline & & & Firm Size & $R O A$ & $S A$ & $C R$ \\
\hline 1. & $\begin{array}{l}\text { Sheluntcova, } \\
\text { Maria (2014) }\end{array}$ & $\begin{array}{l}\text { Multiple } \\
\text { linear } \\
\text { regression }\end{array}$ & (-) sig & (-) sig & (-) sig & (-) sig \\
\hline 2. & $\begin{array}{l}\text { Alipour, } \\
\text { Mohammad, et al. } \\
(2015)\end{array}$ & $\begin{array}{l}\text { Multiple } \\
\text { linear } \\
\text { regression }\end{array}$ & (-) sig & (-) sig & $(+) \operatorname{sig}$ & Not sig \\
\hline 3. & $\begin{array}{l}\text { Acaravci, Songul } \\
\text { Kakilli (2014) }\end{array}$ & $\begin{array}{l}\text { Multiple } \\
\text { linear } \\
\text { regression }\end{array}$ & (-) sig & (-) sig & (-) sig & \\
\hline 4. & $\begin{array}{l}\text { Yousefzadeh, } \\
\text { Nasrin, et al. } \\
(2014)\end{array}$ & $\begin{array}{l}\text { Multiple } \\
\text { linear } \\
\text { regression }\end{array}$ & $(+) \operatorname{sig}$ & (-) sig & $(+) \operatorname{sig}$ & \\
\hline 5. & $\begin{array}{l}\text { Singh, } \\
\text { Dharmendra } \\
(2016)\end{array}$ & $\begin{array}{l}\text { Multiple } \\
\text { linear } \\
\text { regression }\end{array}$ & $(+) \operatorname{sig}$ & (-) sig & (-) sig & (-) sig \\
\hline 6. & $\begin{array}{l}\text { Wahab, Siti NAA } \\
\& \text { Nur Ainna } \\
\text { Ramli (2014) }\end{array}$ & $\begin{array}{l}\text { Multiple } \\
\text { linear } \\
\text { regression }\end{array}$ & (-) sig & Not sig & $(+) \operatorname{sig}$ & $(-) \operatorname{sig}$ \\
\hline 7. & $\begin{array}{l}\text { Pattweekongka, S } \\
\text { \& Kulkanya } \\
\text { Napompech } \\
\text { (2014) }\end{array}$ & $\begin{array}{l}\text { Multiple } \\
\text { linear } \\
\text { regression }\end{array}$ & & (-) sig & $(+) \operatorname{sig}$ & $(-) \operatorname{sig}$ \\
\hline 8. & $\begin{array}{l}\text { Couto, Gualter } \\
\text { and } \\
\text { Chissingui }(2016)\end{array}$ & $\begin{array}{l}\text { Multiple } \\
\text { linear } \\
\text { regression }\end{array}$ & $(+) \operatorname{sig}$ & (-) sig & (-) sig & (+) sig \\
\hline 9. & $\begin{array}{l}\text { Thippayana, } \\
\text { Pornpen (2014) }\end{array}$ & $\begin{array}{l}\text { Multiple } \\
\text { linear } \\
\text { regression }\end{array}$ & $(+) \operatorname{sig}$ & (-) sig & Not sig & \\
\hline 10. & $\begin{array}{l}\text { Serghiescu, L and } \\
\text { Vaidean, } \\
(2014)\end{array}$ & $\begin{array}{l}\text { Multiple } \\
\text { linear } \\
\text { regression }\end{array}$ & $(+) \operatorname{sig}$ & (-) sig & Not sig & $(-) \operatorname{sig}$ \\
\hline 11. & $\begin{array}{l}\text { Gonzales Victor } \\
\text { M \& Francisco } \\
\text { Gonzales (2011) }\end{array}$ & $\begin{array}{l}\text { Multiple } \\
\text { linear } \\
\text { regression }\end{array}$ & & (-) sig & $(+) \operatorname{sig}$ & \\
\hline 12. & $\begin{array}{l}\text { Bauer, } \quad \text { Patrik } \\
(2014)\end{array}$ & $\begin{array}{l}\text { Multiple } \\
\text { linear } \\
\text { regression }\end{array}$ & $(+) \operatorname{sig}$ & (-) sig & (-) sig & \\
\hline 13. & $\begin{array}{l}\text { Masnoon, } \\
\text { Maryam \& Abiha } \\
\text { Saeed (2014) }\end{array}$ & $\begin{array}{l}\text { Multiple } \\
\text { linear } \\
\text { regression }\end{array}$ & Not sig & (-) sig & Not sig & (-) sig \\
\hline
\end{tabular}




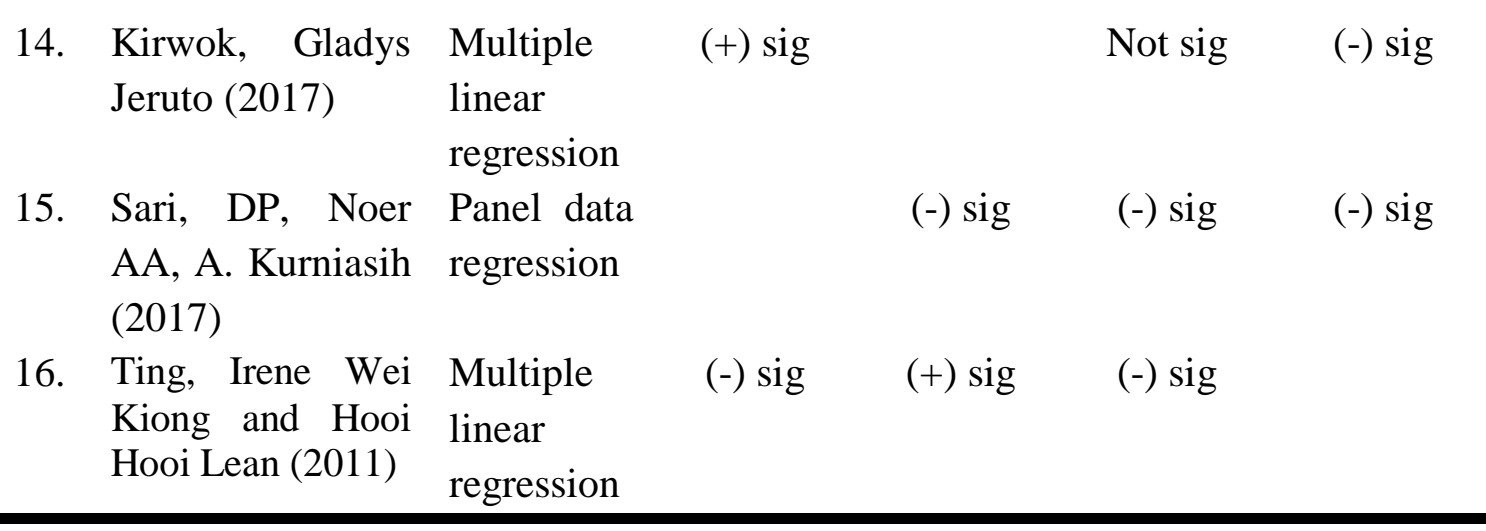

Source: Processed by researchers

\section{RESEARCH METHODS}

\section{Types of research}

This type of research is causality research, namely research that aims to test hypotheses and determine the relationship and influence between two or more variables on other variables. This study aims to examine the effect of independent variables, namely company size, profitability, asset structure and liquidity on the dependent variable, namely capital structure.

\section{Operational Definition and Variable Measurement}

This study uses two types of variables, namely the dependent variable and the independent variable. Capital Structure (Y) in this study is used as the dependent variable. Size $\left(\mathrm{X}_{1}\right)$, Profitability $\left(\mathrm{X}_{2}\right)$, Asset Structure $\left(\mathrm{X}_{3}\right)$, and Liquidity $\left(\mathrm{X}_{4}\right)$ as independent variables.

\section{FINDINGS AND DISCUSSION}

Plantation sub-sector companies dominate the issuers of the agricultural sector on the Indonesia Stock Exchange (IDX). Based on the research limitations, there are 15 issuers that meet the criteria of being listed on the IDX since the beginning of 2014 and consistently delivering financial reports until 2018.

Table 3. List of Samples of Plantation Subsector Issuers on the IDX

\begin{tabular}{cllc}
\hline \hline No. & Code & \multicolumn{1}{c}{ Company Name } & Listing Date \\
\hline \hline 1 & AALI & PT Astra Agro Lestari Tbk & $09 / 12 / 1997$ \\
2 & ANJT & PT Austindo Nusantara Jaya Tbk & $08 / 05 / 2013$ \\
3 & BWPT & PT Eagle High Plantations Tbk & $27 / 10 / 2009$ \\
4 & DSNG & PT Dharma Satya Nusantara Tbk & $14 / 06 / 2013$ \\
5 & GOLL & PT Golden Plantation Tbk & $23 / 12 / 2014$ \\
6 & GZCO & PT Gozco Plantations Tbk & $30 / 05 / 2011$ \\
7 & JAWA & PT Jaya Agra Wattie Tbk & $05 / 07 / 1996$ \\
8 & LSIP & PT PP London Sumatra Indonesia Tbk & $16 / 01 / 2013$ \\
9 & PALM & PT Provident Agro Tbk & $12 / 07 / 2018$
\end{tabular}




\begin{tabular}{llll}
10 & SGRO & PT Sampoerna Agro Tbk & 08/10/2012 \\
11 & SIMP & PT Salim Ivomas Pratama Tbk & $09 / 06 / 2011$ \\
12 & SMAR & PT Sinar Mas Agro Resources and Technology Tbk & $20 / 11 / 1992$ \\
13 & SSMS & PT Sawit Sumbermas Sarana Tbk & $12 / 12 / 2013$ \\
14 & TBLA & PT Tunas Baru Lampung Tbk & $14 / 02 / 2000$ \\
15 & UNSP & PT Bakrie Sumatera Plantations Tbk & $06 / 03 / 1990$ \\
\hline
\end{tabular}

Source: Indonesia Stock Exchange (2019), processed by researchers

Table 4. Descriptive Statistics of Debt to Asset Ratio (DAR) Variables

\begin{tabular}{cccccc}
\hline Tahun & $\mathbf{2 0 1 4}$ & $\mathbf{2 0 1 5}$ & $\mathbf{2 0 1 6}$ & $\mathbf{2 0 1 7}$ & $\mathbf{2 0 1 8}$ \\
\hline Minimum & 0,1540 & 0,1710 & 0,1920 & 0,1647 & 0,1730 \\
Maximum & 0,8610 & 0,8910 & 0,9100 & 1,0220 & 1,1070 \\
Mean & 0,5235 & 0,5545 & 0,5410 & 0,5451 & 0,5674 \\
Std. Dev & 0,1818 & 0,1759 & 0,1895 & 0,2092 & 0,2459 \\
$N$ & 15 & 15 & 15 & 15 & 15 \\
\hline
\end{tabular}

Source: Data Processing Eviews 10

Table 5. Descriptive Statistics of Company Size Variables (in IDR Tn.)

\begin{tabular}{cccccc}
\hline Tahun & $\mathbf{2 0 1 4}$ & $\mathbf{2 0 1 5}$ & $\mathbf{2 0 1 6}$ & $\mathbf{2 0 1 7}$ & $\mathbf{2 0 1 8}$ \\
\hline \hline Minimum & 1,975 & 2,163 & 2,376 & 2,471 & 1,992 \\
Maximum & 30,996 & 31,697 & 33,062 & 33,859 & 34,666 \\
Mean & 10,414 & 11,466 & 12,114 & 12,482 & 13,229 \\
Std. Dev & 8,322 & 8,640 & 9,333 & 9,580 & 10,064 \\
$N$ & 15 & 15 & 15 & 15 & 15 \\
\hline
\end{tabular}

Source: Data Processing Eviews 10

Table 6. Descriptive Statistics of Variables Return on Assets (ROA)

\begin{tabular}{cccccc}
\hline Tahun & $\mathbf{2 0 1 4}$ & $\mathbf{2 0 1 5}$ & $\mathbf{2 0 1 6}$ & $\mathbf{2 0 1 7}$ & $\mathbf{2 0 1 8}$ \\
\hline \hline Minimum & 0,0034 & $-0,0310$ & $-0,4530$ & $-0,1110$ & $-0,1380$ \\
Maximum & 0,1410 & 0,0820 & 0,0990 & 0,0830 & 0,0570 \\
Mean & 0,0560 & 0,0124 & $-0,0013$ & 0,0218 & $-0,0183$ \\
Std. Dev & 0,0395 & 0,0333 & 0,1334 & 0,0602 & 0,0604 \\
$N$ & 15 & 15 & 15 & 15 & 15 \\
\hline
\end{tabular}

Source: Data Processing Eviews 10

Table 7. Descriptive Statistics of Asset Structure Variables (SA)

\begin{tabular}{cccccc}
\hline \hline Tahun & $\mathbf{2 0 1 4}$ & $\mathbf{2 0 1 5}$ & $\mathbf{2 0 1 6}$ & $\mathbf{2 0 1 7}$ & $\mathbf{2 0 1 8}$ \\
\hline Minimum & 0,1650 & 0,5010 & 0,4680 & 0,4500 & 0,3140 \\
Maximum & 0,9010 & 0,9190 & 0,9176 & 0,9165 & 0,8890 \\
Mean & 0,6061 & 0,6861 & 0,6820 & 0,6855 & 0,6241
\end{tabular}




\begin{tabular}{cccccc} 
Std. Dev & 0,1879 & 0,1207 & 0,1274 & 0,1481 & 0,1757 \\
$N$ & 15 & 15 & 15 & 15 & 15 \\
\hline
\end{tabular}

Source: Data Processing Eviews 10

Table 8. Current Variable Descriptive Statistics (CR)

\begin{tabular}{cccccc}
\hline Tahun & $\mathbf{2 0 1 4}$ & $\mathbf{2 0 1 5}$ & $\mathbf{2 0 1 6}$ & $\mathbf{2 0 1 7}$ & $\mathbf{2 0 1 8}$ \\
\hline Minimum & 0,1812 & 0,1837 & 0,1152 & 0,1272 & 0,0421 \\
Maximum & 7,3870 & 2,2210 & 3,2853 & 5,5226 & 5,2770 \\
Mean & 1,3148 & 0,9678 & 1,1956 & 1,4396 & 1,5417 \\
Std. Dev & 1,7648 & 0,5015 & 0,8145 & 1,5304 & 1,4925 \\
$N$ & 15 & 15 & 15 & 15 & 15 \\
\hline Sounc
\end{tabular}

Source: Data Processing Eviews 10

\section{Table 9. Stationary Test of DAR Variables}

Null Hypothesis : $D(D A R)$ has a unit root

Exogenous: Constant

Lag Length: O (Automatic - based on SIC. maxlag=11)

\begin{tabular}{rcc}
\hline & t-statistic & Prob. $^{*}$ \\
\hline Augmented Dickey-Fuller test statistic & -11.22558 & 0.0001 \\
\hline $1 \%$ level & -3.522887 & \\
$5 \%$ level & -2.90177 & \\
$10 \%$ level & -2.588280 & \\
\hline \hline
\end{tabular}

Source: Data Processing Eviews 10

Table 10. Stationary Test Variable Company Size (SIZE)

\begin{tabular}{lcc}
\hline Null Hypothesis : D(SIZE) has a unit root & \\
Exogenous: Constant \\
Lag Length: O (Automatic - based on SIC. maxlag=11) \\
\hline & t-statistic & Prob. $^{*}$ \\
\hline Augmented Dickey-Fuller test statistic & -8.537526 & 0.0000 \\
\hline $1 \%$ level & -3.522887 & \\
$5 \%$ level & -2.901779 & \\
$10 \%$ level & -2.588280 & \\
\hline
\end{tabular}

Source: Data Processing Eviews 10

Table 11. Stationary Test of ROA Variables

\begin{tabular}{|c|c|c|}
\hline \multicolumn{3}{|c|}{$\begin{array}{l}\text { Exogenous: Constant } \\
\text { Lag Length: } 0(\text { Automatic }- \text { based on SIC. } \text { maxlag }=11)\end{array}$} \\
\hline & $t$-statistic & Prob.* \\
\hline Augmented Dickey-Fuller test statistic & -6.157160 & 0.0000 \\
\hline
\end{tabular}




\begin{tabular}{rr}
\hline \hline $1 \%$ level & -3.521579 \\
$5 \%$ level & -2.901217 \\
$10 \%$ level & -2.587981 \\
\hline \hline
\end{tabular}

Source: Data Processing Eviews 10

Table 12. Stationary Test of ROA Variables

\begin{tabular}{lcc}
\hline Null Hypothesis : $D(S A)$ has a unit root & \\
Exogenous: Constant \\
Lag Length: O (Automatic - based on SIC. maxlag=11) \\
\hline & t-statistic & Prob. $^{*}$ \\
\hline Augmented Dickey-Fuller test statistic & -6.453454 & 0.0000 \\
\hline $1 \%$ level & -3.521579 & \\
$5 \%$ level & -2.901217 & \\
$10 \%$ level & -2.587981 & \\
\hline
\end{tabular}

Source: Data Processing Eviews 10

Table 13. Descriptive Statistics of Current Ratio (CR) Statistics

\begin{tabular}{|c|c|c|}
\hline $\begin{array}{l}\text { Null Hypothesis : } D(C R) \text { has a unit root } \\
\text { Exogenous: Constant } \\
\text { Lag Length: } 0 \text { (Automatic - based on SI }\end{array}$ & $\operatorname{maxlag}=11$ & \\
\hline & $t$-statistic & Prob.* \\
\hline Augmented Dickey-Fuller test statistic & -6.299649 & 0.0000 \\
\hline $1 \%$ level & -3.521579 & \\
\hline $5 \%$ level & -2.901217 & \\
\hline $10 \%$ level & -2.587981 & \\
\hline
\end{tabular}

Source: Data Processing Eviews 10

\section{Discussion}

Based on the analysis of the results of the research described previously, this section describes the discussion to prove the hypothesis. The discussion was carried out by describing the strong influence between independent variables consisting of SIZE, ROA, SA and CR on DAR on plantation subsector companies listed on the Indonesia Stock Exchange during the period 2014 to 2018. Description of the strength of influence between variables then compared with empirical evidence that obtained in the field and theories that support the hypothesis. The following stages of the discussion are based on the path between the variables in the model.

\section{Analysis of the Effect of Company Size on Capital Structure}

T-test results of company size variables indicate that Company Size (SIZE) partially has no effect on DAR. These results are not in line with the hypothesis which states that company size is suspected to have a negative effect on Capital Structure proxied by DAR. The results showed that Company Size (SIZE) has not been taken into consideration in 
determining DAR, this is because the company's total assets are not the only factor that determines the company's capital structure. In carrying out its financing activities, the company will first use internal funds, then only use loans from external parties or offer shares to obtain capital.

The results of this study reinforce several previous studies, including Liem (2013), Hartoyo (2014) and Masnoon (2014). In contrast, the results of this study are not in line with research by Sheluntcova (2014), Acaravci (2014), Alipour (2015) and Wahab (2014) who state that CR has a negative effect on DAR.

\section{Analysis of the Effect of Return on Assets (ROA) on DAR}

T-test results of profitability variables (ROA) indicate that ROA partially has a negative effect on DAR. Thus, these results are in line with the hypothesis which states that profitability (ROA) is thought to have a negative effect on Capital Structure proxied by DAR. Its negative influence is supported by research data, for example between 2014 to 2018, in average LSIP has a ROA $6.9 \%$ with a debt to total asset ratio (DAR) of $17.9 \%$, while in average UNSP which has a lower ROA of $-5.3 \%$ has a higher DAR of $95.8 \%$.

Increased profitability as indicated by ROA will further strengthen the company's capital structure. Generally, the better the company's capital structure, the less likely it is that the Company will seek external funding through bank debt or bond issuance. This is based on the Pecking Order Theory where investors will prioritize the use of internal funds owned by the company (Myers, 1984).

The results of this study reinforce several previous studies, including Sari (2017), Sheluntcova (2014), Alipour (2015), and Couto (2016). In contrast, the results of this study are not in line with Ting (2011) who state that CR has a positive effect on DAR.

\section{Analysis of the Effect of Asset Structure on Capital Structure}

The $t$ test results of the Asset Structure variable (SA) indicate that SA partially has a positive effect on DAR. Its positive influence is supported by research data, for example between 2014 to 2018, in average LSIP has a SA 60.4\% with a debt to total asset ratio (DAR) of $17.9 \%$, while in average JAWA which has a higher SA of $90.5 \%$ has a higher DAR of $68.3 \%$. Thus, these results are in line with the hypothesis which states that Asset Structure (SA) is thought to have a positive effect on Capital Structure proxied by DAR.

The results of this study reinforce several previous studies, including Alipour (2015), Yousefzadeh (2014), Pattweekongka (2014), Liem (2013), who stated that CR had a significant positive effect on DAR. In contrast, the results of this study are not in line with research by Couto (2016), Sheluntcova (2014), Bauer (2014) and Ting (2011) who state that CR has a negative effect on DAR.

\section{Analysis of the Effect of Liquidity (CR) on DAR}

Liquidity variable $t$ test results indicate that the Current Ratio (CR) partially has no effect on the DAR. As such, these results are not in line with the hypothesis that liquidity proxied by Current Ratio (CR) is thought to have a positive effect on Capital Structure proxied by DAR. If the company's liquidity is in good condition, the Company will more 
easily obtain financing for its working capital needs so that the Company's capital structure tends to increase with a relatively low level of risk. With a low level of risk it will attract creditors and debt bond investors to provide funding to the company.

The results of this study reinforce several previous studies, including Alipour (2015) and Margaretha (2010), who stated that CR had no significant effect on DAR. In contrast, the results of this study are not in line with research by Couto (2016), Ridloah (2011) and Nugroho (2011) who state that CR has a positive effect on DAR neither Sheluntcova (2014), Pattweekongka (2014) and Serghiescu (2014) who state that CR has a negative effect on DAR.

\section{CONCLUSION AND SUGGESTION}

\section{Conclusion}

Based on the results of testing and data analysis using the Fixed Effect Model on SIZE, ROA, SA and CR variables, it can be concluded as follows:

1. The results showed that company size did not affect DAR

2. The results show that ROA has a negative effect on DAR

3. The results showed that the Asset Structure (SA) had a positive effect on DAR

4. The results showed that liquidation (CR) had no effect on DAR.

\section{Suggestion}

Based on the results of the discussion and conclusions regarding the variables which include SIZE, ROA, SA and CR on DAR in plantation sub-sector companies, researchers would like to propose suggestions for consideration as follows:

1. For the management of plantation subsector companies listed on the Indonesia Stock Exchange (BEI) in 2014 - 2018 before determining the capital structure, it should consider the variables that affect the capital structure, namely ROA and SA.

2. Based on the research results it is known that the size of the company does not affect DAR, so it is recommended to investors who will invest their shares not to focus on the size of the company alone, because even if the company is a large company, the company will tend to use its own capital and debt as a complement.

3. Based on the results of the study it is known that liquidation has no effect on DAR, this shows that the plantation sector companies listed on the Indonesia Stock Exchange in 2014 - 2018 use a little long-term debt. So it is advisable for investors to pay attention to the level of company liquidity before investing, because companies that have high liquidity will tend to use their own capital.

4. The addition of variables that affect capital structure such as business risk, growth, managerial ownership, type of company, is not limited to using only the variables in this study.

\section{REFERENCE}

Acaravci, S. K. (2014). "The Determinants of Capital Structure: Evidence from the Turkish Manufacturing Sector". International Journal of Economics and Financial Issues. Vol. 5 No. 1, 158-171. 
Alipour, M., Mohammadi, M. F. S., \& Derakhshan, H. (2015). "Determinants of Capital Structure: an Empirical Study of Firms in Iran". International Journal of Law and Management. Vol. 57 No. 1, 53-83.

Bauer, Patrik. (2014). "Determinants of Capital Structure Empirical Evidence from the Czech Republic." Czech Journal of Economics and Finance. Vol. 1, 2-21.

Baker, M. and Wurgler, J. (2002), "Market Timing and Capital Structure", Journal of Finance, Vol. 57 No. 1, 1-32.

Cornelli, F., Portes, R., Schaffer, M. (1996), "The Capital Structure of Firms in Central and Eastern Europe". CEPR Discussion Paper, 1392. 1-35

Couto, G. \& Victor Chissingui. (2016) "Determinant Factors of Capital Structure: an Application to the Portuguese Market”. Egitania Sciencia Journal. Vol. 4 (1), 176 - 195

Firnanti, F. (2011). "Faktor-faktor yang Mempengaruhi Struktur Modal Perusahaan Manufaktur di Bursa Efek Indonesia”. Jurnal Bisnis dan Akuntansi. Vol. 13, 119-128.

Gonzales Victor M \& Francisco Gonzales. (2012). "Firm Size and Capital Structure: Evidence Using Dynamic Panel Data.” Applied Economics. Vol. 44, 4745-4754.

Hall, G.C., Hutchinson, P.J. and Michaelas, N. (2004), "Determinants of capital structures of European SMEs", Journal of Business Finance and Accounting, Vol. 31 No. 5/6, $711-728$.

Hanafi, MM dan Halim, A. (2005). Analisis Laporan Keuangan. UPP AMP YKPN: Yogyakarta.

Hartoyo, A. K. W., Khafid, M., \& Agustina, L. (2014). "Faktor-Faktor yang Mempengaruhi Struktur Modal Perusahaan Tekstil dan Garmen di BEI”. Accounting Analysis Journal. Vol. 3 (2), 158-172.

Jensen, M. and Meckling, W. (1976). "Theory of the firm: Managerial Behavior, Agency Cost and Ownership Structure”, Journal of Financial Economics, Vol. 43, 271-281.

Joni, J., \& Lina, L. (2010). Faktor-Faktor yang Mempengaruhi Struktur Modal. Jurnal Bisnis dan Akuntansi. Vol. 12(2), 82-97.

Kirwok, Gladys Jeruto. (2017). "Determinants of Capital Structure in the Automobile Industry: Case Study Nakuru Town". International Journal of Innovative Research \& Development. Vol. 6 Issue 9, 226 - 259.

Liem, J. H., Murhadi, W. R., \& Sutejo, B. S. (2013). "Faktor-Faktor yang Mempengaruhi Struktur Modal pada Industri Consumer Goods yang Terdaftar di BEI Periode 20072011”. Calyptra: Jurnal Ilmiah Mahasiswa Universitas Surabaya. Vol.2 No.1, 1-11.

Margaretha, F., \& Ramadhan, A. R. (2010). "Faktor-faktor yang Mempengaruhi Struktur Modal pada Industri Manufaktur di Bursa Efek Indonesia". Jurnal Bisnis dan Akuntansi. Vol 12 (2), Hal. 119-130. 
Maryanti, E. (2016). "Analisis Profitabilitas, Pertumbuhan Perusahaan, Pertumbuhan Penjualan dan Struktur Aktiva terhadap Struktur Modal pada Perusahaan Sektor Industri Barang Konsumsi yang terdaftar di Bursa Efek Indonesia (Studi Empiris pada Perusahaan Manufaktur yang Terdaftar di Bursa Efek Indonesia Tahun 20122014)". Riset Akuntansi dan Keuangan Indonesia. Vol. 1 (2), 143-151.

Masnoon, Maryam \& Abiha Saeed. (2014). "Capital Structure Determinants of KSE Listed Automobile Companies”. European Scientific Journal. Vol. 10, No. 13, 451 - 461.

Modigliani, F. and Miller, M.H. (1958), "The Cost of Capital, Corporation Finance and the Theory of Investment”. American Economic Review. Vol. 48, 261-297.

Modigliani, F. and Miller, M.H. (1963), "Corporate Income Taxes and the Cost of Capital: a Correction”. American Economic Review. Vol. 53 No. 3, 433-443.

Miller, M. (1977), “Debt and Taxes”, Journal of Finance. Vol. 32, 261-275

Myers, S. C. and Majluf, N. (1984). "Corporate Finance and Investment Decisions When Firms Have Information That Investors Do Not Have". Journal of Financial Economics. Vol. 13, 187-221

Nugroho, Sigit Dani, Hermanto Siregar, Adler Haymans Manurung dan Nunung Nuryartono. (2015). "Determinan Struktur Modal Perusahaan Perkebunan di Bursa Efek Indonesia." Finance and Banking Journal. Vol. 17, No. 02, 79 - 90.

Nuswandari, Cahyani (2013). "Determinan Struktur Modal dalam Perspektif Pecking Order Theory dan Agency Theory". Jurnal Dinamika Akuntansi Keuangan dan Perbankan, Vol. 2 (1), 92-102.

Pattweekongka, S \& Kulkanya Napompech. (2014). "Determinan Struktur Modal dalam Perspektif Pecking Order Theory dan Agency Theory". Jurnal Dinamika Akuntansi Keuangan dan Perbankan. Vol. 2(1), 117 - 124.

Ridloah, S. (2010). "Faktor Penentu Struktur Modal: Studi Empirik pada Perusahaan Multifinansial". Jurnal Dinamika Manajemen. Vol. 1 (2), 91-101

Sari, DP, Noer AA, Augustina Kurniasih. (2017). "Determinant of Long-Term Liabilities the Agricultural Company: Empirical Evidance from the Indonesian Stock Exchange". International Journal of Current Research in Multidisciplinary. Vol. 2, No. 7, 14 - 20.

Serghiescu, L and Viorela-Ligia Vaidean. (2014). "Determinant Factors of the Capital Structure of a Firm - an Empirical Analysis". Procedia - Social and Behavioral Sciences. Vol. 15, 1447 - 1457.

Sheluntcova, M. (2014). "Capital Structure of Private Pharmaceutical Companies in Russia”. International Journal of Economics \& Management, Vol. 8 No. 2, 114-120.

Singh, D. (2016). "A Panel Data Analysis of Capital Structure Determinants: an Empirical Study of Non-Financial Firms in Oman". International Journal of Economics and Financial Issues, Vol. 6 No. 4, 130-145. 
Sudarno, Riza FH. (2013). “Analisis Faktor-Faktor yang Mempengaruhi Struktur Modal pada Perusahaan Manufaktur Terdaftar di Bursa Efek Indonesia Periode 2007 - 2011”. Diponegoro Journal of Accounting, Vol. 2, No. 2, 1-12.

Thippayana, Pornpen. (2014). "Determinants of Capital Structure in Thailand" Procedia Social and Behavioral Sciences. Vol. 143, 1074 - 1077

Ting, Irene Wei Kiong and Hooi Hooi Lean. (2011). "Capital Structure Of GovernmentLinked Companies In Malaysia”. Asian Academy of Management Journal of Accounting and Finance, Vol. 7, No. 2, 137 - 156.

Wahab, Siti Nur Aqilah Ab \& Nur Ainna Ramli. (2014). "Determinants of Capital Structure: An Empirical Investigation of Malaysian Listed Government Linked Companies (GLCs)". International Journal of Economics and Financial Issues. Vol. 4 No. 4, 930-945.

Yousefzadeh, N., Aazami, Z., Shamsadini, H., \& Abousaiedi, M. (2014). "Determinants of Capital Structure of Iranian Companies Listed in Tehran Stock Exchange: A structural Equation Modeling Approach". Indian Journal of Commerce and Management Studies, Vol. 5 No. 2, 73-81.

Yusintha, P., \& Suryandari, E. (2016). Analisis Faktor-faktor yang Mempengaruhi Struktur Modal. Journal of Accounting and Investment, Vol. 11 (2), 179-188. 